\title{
Kanyó Mária
}

\section{A társadalom „szövetét” alkotó jelképi kultúra mint a közösséget integráló kötőanyag}

\section{The Symbolic Culture That Makes Up the 'Fabric' of Society as a Binder That Integrates the Community}

\begin{abstract}
Absztrakt
A kultúra fogalmának meghatározásakor számos definíció az alkotóelemeket emeli ki. A Magyar nyelv értelmező szótára is a kultúra összetevőinek két nagy csoportja kiemelésével határozza meg a kultúrát, mint az emberiség által létrehozott anyagi és szellemi értékek összességét. Az előbbiek az emberek által létrehozott anyagi természetü létezőket magában foglaló anyagi kultúra, az utóbbi a jelképi kultúra, amely a jelképi természetü létező́ket foglalja magában. Mások materiális (tárgyiasult) és immateriálisnak (szellemi) nevezett elemekre bontják. ${ }^{2}$

Tanulmányomban a kultúra szükebb értelmezését jelentő, jelképi kultúrával foglalkozom. Be kívánom mutatni, hogy a jelképi kultúra az emberi társulások "szövetét", összetartó erejét alkotja, s mint ilyen, a közösséget integráló és egyben kontrolláló eröként funkcionál. A jelképi kultúra elemeinek kibontásával érzékeltetem, hogy a társadalmakáltaluk teremtenek rendezettséget, visznek kiszámíthatóságot a jelenségek kaotikus világába.
\end{abstract}

Kulcsszavak: kultúra, civilizáció, értékrendszer, norma, szimbólum

\section{Abstract}

When defining the concept of culture, a number of definitions highlight the components. The Hungarian Interpretive Dictionary also defines culture as two 'groups of material

Nemzeti Közszolgálati Egyetem, címzetes egyetemi tanár - University of Public Service, Honorary Professor, e-mail: kanyo.maria@uni-nke.hu, ORCID: https://orcid.org/0000-0002-0619-9546

2 Rudnák Ildikó: A multikulturális környezet kihívásai a magyarországi nagyvállalatok vezetői körében. Doktori értekezés. Gödöllő, Szent István Egyetem, 2010. 11. 
and spiritual values created by humanity', highlighting two major groups of cultural components. The former is the material culture that includes beings of a material nature created by humans, while the latter, the symbolic culture includes beings of a symbolic nature. Others break it down into elements called tangible (objectified) and intangible (spiritual). In my study, I deal with the narrower, symbolic culture. I want to show that symbolic culture is the 'connecting fabric', the cohesive force of human associations, and as such, it functions as a force that integrates and controls the community. By unfolding the elements of symbolic culture, I demonstrate that societies create with them order in the disordered reality, bring predictability into the chaotic world of phenomena.

Keywords: culture, civilisation, value system, norm, symbol

\section{A jelképi kultúra identitásteremtő világa}

A jelképi kultúra áttekintése során a "másodlagos kultúrának"3 is nevezett, kognitív és normatív elemeket felölelő kulturális mezővel foglalkozom, amelynek során annak összetevőit: az adott emberi közösségben érvényes értékrendszert, az általánosan elfogadott viselkedési normákat és a szimbolikus teret vizsgálom.

Amikor emberi társadalomról beszélünk, egyúttal kultúráról is szó van. Társadalom nem létezhet kultúra nélkül, az minden népnek van, legfeljebb más, és ez a másság különbözteti meg őket. „A kultúra az emberi közösségek számára azt jelenti, mint az egyének számára az egyéniség [...] azaz az önmagával való azonosságot határozza meg." „Kulturálatlan” nép nincs, a törzsi viszonyok között élő szociális közösség is „ugyanolyan értékü" kultúrával bír, mint a modern kor társadalmai. A kultúra mindig az „egyetemesnek egy változatát jelenti, valamely közösség, nép, nemzet összetartozását szolgálja". ${ }^{5}$ Geertz nézete szerint a bali kakasviadal ugyanazt nyújtja a bali emberek számára, mint amit más vérmérsékletủ és más hagyománnyal rendelkező népeknek a Lear király és a Bün és bünhődés ad. ${ }^{6}$ A törzsi közösségeknek is ugyanúgy megvannak az isteneik, a közösséget szabályozó normáik, a követendő értékeik, ünnepeik, nyelvük, a gazdag szimbólumrendszerük. Amint Elias a „kultúra” és a „civilizáció” szociogenezisének feltárása során kifejti, legfeljebb a civilizációs folyamat fejlődése során nem történt meg az a fajta elindulásuk, mint ami a 16. századi európai társadalmakban megtörtént, és továbbhaladt a viselkedésváltozás társadalmiszükséglet-igényén. ${ }^{7}$

\footnotetext{
A kultúra anyagi részeit „elsődleges kultúrának” is szokás nevezni, míg „másodlagos kultúra” alatt az értékek, normák, szimbólumok világa értendő. Falkné Bánó Klára: Kultúraközi kommunikáció. Az interkulturális menedzsment aspektusai. Budapest, Perfekt, 2008. 25.

4 Geert Hofstede: A kultúra következményei. Értékek, magatartásformák, intézmények és szervezetek összehasonlítása az egész nemzetek között. Tilburgi Egyetem, 2011. Geert Hofstede: Culture's Consequences. International Differences in Work-Related Values. Beverly Hills - London, Sage, 1980. 25.

Vitányi Iván: A kultúra szerepe a társadalomban és a demokráciában. Beszélő, (2016), március 6. 2.

Clifford Geertz: Az értelmezés hatalma. Antropológiai írások. 2. kiadás. (Válogatás, utószó Niedermüller Péter). Budapest, Osiris. 2001. 181-182.

Norbert Elias: A civilizáció folyamata I-II. Budapest, Gondolat, 1987. 141-148., 162-178. A civilizációs folyamatnak a kezdeti szakaszát Rotterdami Erasmusnak a gyermekek „viselkedésbeli jólneveltségéről” írt kézikönyve (De civilitate morum puerilium) alapján részletesen taglalja, miután itt fogalmazódik meg a civilizáció sajátos értelme, amely napjainkig meghatározza a társadalmi magatartás irányelveit. Megemlíti, hogy e könyv alapján honosodott meg a „civilizáció" kifejezés, mint az emberi viselkedés kívánatos pallérozása.
} 
Weber szintén különbséget tesz a kultúra és a civilizáció között. ${ }^{8}$ Hankiss nem tesz distinkciót, nézete szerint a „kultúra” és a „civilizáció” fogalmának kezdetektől fogva lényege, nélkülözhetetlen alkotóeleme volt a magatartás korlátozása, a természetes, ösztönös lény pallérozása, az ösztönök, vágyak, félelmek visszaszorítása. ${ }^{9}$ A német gondolatkörben, más formában, máig ható érvénnyel választják külön a civilizációt és a kultúrát. Értelmezésük szerint a civilizáció inkább külső formákat, a kultúra inkább belső értékeket jelöl.

A társadalom kultúrája szerteágazó, szövevényes mintázattal rendelkezik. Az a sokrétü „kötőanyag”, amely összefogja, egységes keretbe integrálja az adott entitást, tagjai számára az önazonosság megélésének élményét teszi lehetővé. Identitást ad a közösségnek, s egyben egy információrendszer, amely a kódok ismerete által segíti az embereket egymás megértésében. A kultúra kollektív mintázatainak átörökítése biztosítja annak folytonosságát. Valójában a világot a kultúránk - összetevői által alkotott - szemüvegén keresztül szemléljük és értelmezzük. A kultúránk határozza meg többek között, hogy az ember életében legfeljebb egyszer látható teljes napfogyatkozást babonás félelemmel vagy tudományos tájékozódással szemléljük. ${ }^{10}$

Kultúránk biztosítja az „otthonosságot”, a „mi” kategóriáit. Ezért kötődünk azokhoz az értékekhez, eljárásokhoz, értelmezésekhez, amelyeket kultúránk elsajátításakor magunkba szívtunk. A szocializáció során elsajátított „közös tudat” ismeretanyaga jelenti azt a folyamot, amelyen haladva a közösség tagjai „félszavakból is megértik egymást". Ez teszi lehetővé, hogy bonyolult összefüggéseket, jelentéseket nem mindenkor szükséges részletesen kifejteni, elégséges csupán utalni rájuk valamilyen jelzéssel.

\section{A társadalmi együttélést biztosító, közösséget szabályozó normarendszer}

A normák az intézményesült rendből származnak, „a normativitás a társadalmi lét egészében gyökerezik, annak egyfajta tárgyiassági formája".11 Egy kulturális közösség társadalmi együttélésének feltétele, hogy legyenek szabályok, úgymond cövekek, hogy „eddig és ne tovább", azaz olyan eligazító pontok, amelyek jelzik, hogy az adott közösségben mi az irányadó magatartás, mi a helyes, és mi nem az, melyek a kívánatosnak tartott cselekvés- és életmódok, a követendő értékek. Az írott és íratlan normák ezt az eligazító, szabályozó szerepet töltik be minden társadalomban, függetlenül attól, hogy koronként és társadalmanként különbözőek (lehetnek). A társas viszonyok szabályozásának követelményét korán felismerték, „a társadalmi normák léte egyidős az emberi társadalommal. Minden típusa a helyes, a követendő magatartásformát írja

8 Pangákisz a két fogalom értelmezését vizsgálja a különböző tudományágak teoretikusainál. Álláspontja szerint Weber a kultúra fogalmával az individuum szellemi műveltségét jelöli, amely kapcsolatos az emberi résztvétellel a kultúra létrehozásában, a civilizáció fogalmával a résztvétel mértékét és jellegét jelöli. Grigóriosz L. Pangákisz: Civilizáció és kultúra. Kultúra és Közösség, 7. (2003), 1. 71.

9 Hankiss Elemér: Proletár reneszánsz. Tanulmányok az európai civilizációról és a magyar társadalomról. Budapest, Helikon, 1999. 37.

10 Gordon W. Allport: A személyiség alakulása. Győr, Kairosz, 1998. 186.

11 Szigeti Péter: Norma és valóság. Győr, Széchenyi István Egyetem, MTA Politikai Tudományok Intézete 2006. 6. 
elő, melyek képesek az emberi cselekedetek befolyásolására és irányítására."12 Heller utal rá, hogy a normák és szabályok differenciáltak. Lehetnek parancsoló erejüek, illetve választhatóak, valamint óhajtást is kifejezhetnek. A parancsoló erejü normák és szabályok feltétlenek, azaz kategorikusak, előírják, mit kell és mit nem szabad tennünk, illetve megtilt bizonyos cselekvést, megszegésük büntetésért kiált.13 $\mathrm{A}$ primitív társadalmakban a szokásokba beleszövődött értékelemek normatív funkciója csírájában már kitapintható, azonban a normák mint kötelező elvárások mintakénti müködése csak a későbbiekben honosodott meg. ${ }^{14}$

A normarendszerek különbözőségeiben foglalt tartalom tükrözi az egyes közösségeknek a világról alkotott képét, önmagáról vélekedését, másokról való szemléletmódját, és közös értelmezési keretet nyújt az élet dolgairól. Bár a különböző cselekvési szituációkban az egyéneknek mozgásterük van szerepfelfogásuk, viselkedésük alakítására, mindazonáltal a kultúra alkotórészeit képező szabályok és a - társadalmi élet különböző terepein betöltött - szerepekhez füződő elvárások alapvetően meghatározzák magatartásukat. ${ }^{15}$ Mindez előmozdítja a társadalmi rend kiszámíthatóságát, amelynek feltétele, hogy az egyes egyének meghatározott szabályok, eljárásmódok keretei között cselekedjenek. Ennek megvalósulása teszi lehetővé, hogy bizonyos magatartást mások tekintetében elvárjunk, és azzal számolhassunk.

A szabályozó szerep érvényesülését törvényekkel és pozitív (jutalmazó), illetve negatív (büntető) jellegű szankciókkal támasztják alá. Durkheim a közösség létérdeke felől közelíti meg a (szabályszegő) bünös fogalmának értelmezését. Szerinte egy tett „nem azért sérti a közös tudatot, mert bűnös, hanem azért bűnös, mert sérti a közös tudatot. Nem azért utasítjuk el, mert bűntett, hanem azért bűntett, mert elutasítjuk."16 Végső fokon az így megerősített elvek, szabályok teszik lehetővé a társadalmi együttélést, együttműködést. A szociális közösséget regulázó „szabálynak az a funkciója, hogy megelőzze a közös tudat ${ }^{17}$ és következtetésképpen a társadalmi szolidaritás minden megrázkódtatását"18 A büntetés szerepét is abban látja, hogy az a társadalom tagjai felé a határvonalak jelzése, egy intelem, amely a normarendszer megbomlott egyensúlyát hivatott visszaállítani. Foucault a társadalmi normákat megsértőkkel szembeni büntetés történetét vizsgálva ${ }^{19}$ ugyancsak hangsúlyozza a büntetésnek (a bünelkövető mellett) a társadalom tagjai felé irányuló funkcióját, a normák megerősítését. Ez szembeötlően a 19. század előtt volt jelen, a büntetés - megfélemlítésre rendezett - látványossága

\footnotetext{
Csink Lóránt - Mayer Annamária: Variációk a szabályozásra. Budapest, Médiatudományi Intézet, 2012. 10.

Heller Ágnes: Általános etika. Budapest, Cserépfalvi, 1994. 45-48.

Heller Ágnes: A szándéktól a következményig. Budapest, Magvetö, 1970. 46-54.

Erving Goffman: A hétköznapi élet szociálpszichológiája. Budapest, Gondolat, 1981. 10. 21.

Emile Durkheim: A társadalmi munkamegosztásról. Budapest, MTA Szociológiai Kutató Intézet, 1986. 58.

Durkheim közös vagy kollektív tudatnak nevezi a meggyőződéseknek és érzéseknek az együttesét, amely közös egy adott társadalom átlagos tagjaiban, meghatározott rendszert alkot, amelynek saját élete van. Durkheim (1986) i. m. 7

18 Durkheim (1986) i. m. 206.

19 Michel Foucault: Felügyelet és büntetés. Budapest, Gondolat, 1990. A könyv a börtönök történetével párhuzamosan bemutatja a különböző korokban a társadalmi regulázás eszközeit, valamint a büntetés „tárgyának” változását. Míg a 19. század előtt a test a törvényes megtorlás céltáblája, majd a modern büntető rendszerben „tárgycsere" történik, és célpont a lélek lesz. A büntetés „szemérmessé válik”.
} 
által, ${ }^{20}$ majd akkortól megszűnik a színpadias formája és a büntetés javító jellegének meghatározása kerül előtérbe.

\section{A kultúra építököveit alkotó értékek}

A társadalmi szabályozás összekapcsolódik az értékekkel, a normák mindig a mögöttük lévő értékek kifejezői. „Az értékek magva mindég a normatív szférában keresendő."21 Ugyanakkor kapcsolatuk dinamikus, mert az értékek azáltal, hogy a „kell” igényével, elvártságával rendelkeznek, további szabályrendszereket generálnak. Az értékekben érhető tetten, hogy a közösség mit tart „jónak”, ,értékesnek”, ami megóvandó és megőrzendő. Mi a kívánatos, előnyben részesítendő és mi a nem kívánatos a közösség léte szempontjából és hátránnyal sújtható. ${ }^{22} \mathrm{Az}$ értékek kulturális alapelvek, a kultúra építőkövei: érvényesülésüket szolgálják a normák, tudatosítását (többek között) az ünnepek, példaképek állítása, megörzését a szokásjellegű szimbolikus cselekvések és a szimbólumrendszerek világa, átörökítését a fennálló intézményeken belüli és az azon kívüli szférák „értékközvetítő" csatornái.

Az értékek a normákhoz hasonlóan koronként és társadalmanként változnak, azaz „olyan társadalom-, illetve kultúrspecifikus eszmei objektivációk, amelyekben az emberek szelektív és értékelő viszonya fejeződik ki meglevő világukhoz, társadalmi és természeti jelenségekhez, egymáshoz, tevékenységfajtákhoz és nem utolsósorban önmagukhoz". ${ }^{23}$ Mindemellett léteznek egyetemes, kultúrákon átívelö értékek és erkölcsi normák. Azonban még az úgynevezett örök emberi vagy univerzális értékek esetében is kiviláglik azoknak a konkrét társadalmi és élethelyzetekhez kötött jellege. Az adott társadalomban alapvetőnek tekintett értékek érvényesülését a belőlük fakadó további, másod-, harmadlagos értékek realizálódása követi, mintegy kiterjesztve az alapértékek hatósugarát. A modern társadalmakban az emberi élet felbecsülhetetlen érték, és minden körülmények közötti megóvása, az életvédelem erkölcsi kötelesség. Ezzel szemben a rabszolgatartó társadalmakban az emberi élet nem számított alapvető értéknek, a rabszolgákat helyenként "beszélő gépeknek" tekintve, a legdurvábban gázoltak át a humánumon. Ebből következően e társadalmakban nem volt számon kérhető az együttérzés, az emberség, a tolerancia, a „nem ártunk másoknak” mint az életvédelem kiteljesítő értékei, amelyek korunkban testet öltve, az alapérték újbóli megerősítését jelzi a közösség tagjai számára. A kora középkorra jellemző állandó háborúskodás, harc helyett - amikor az örökös küzdelem, kegyetlenség, a halált megvető bátorság alapértékekként határozták meg a kívánatos magatartást-, a modern kor a békét emeli az alapértékek sorába. Érvényesülését kiterjesztve és megerősítve a bizalom, az erőszak-nélküliség, a más kultúrák elfogadása, levezetett értékeivel,

20 A büntető szertartások színpadias jellegüek, az ítélet-végrehajtás a nép jelenlétében zajlik. A szertartás révén a nép előtt a hatalom manifesztálódik, az erők aránytalanságának megfordíthatatlanságát is tükrözi. A kínhalálnak politikai funkciója is van, mintegy helyreállítja a megsértett rendet. Foucault (1990) i. m. 21-39.

21 William L. Kolb: Az értékfogalom jelentőségének változása a mai szociológiai elméletben. In Balog L. (szerk.): Modern polgári szociológia IV. Budapest, Tankönyvkiadó, 1966. 247.

22 Andorka Rudolf: Bevezetés a szociológiába. Budapest, Osiris, 1997. 490.

23 Váriné Szilágyi Ibolya: Az ember, a világ és az értékek világa. In Lengyel Zsuzsanna (szerk.): Szociálpszichológia. Budapest, Osiris, 1997. 133. 
és a nemzetek megszületésével a hazafias erények is központi helyet foglalnak el az értékskálában.

Farkas megkülönbözteti a közösségi és a társadalmi értékeket, bár hangsúlyozza, hogy a kettő között sincs éles határ, részben áthatják egymást, vagy akár erősíthetik, illetve gyengíthetik is a másikat. A közösségi érték, „amellett, hogy (1) valamennyi egyén tudatának az alkotórészét képezi, (2) az adott értékröl valamennyi egyén feltételezi, hogy az adott körben mások tudatának is az alkotórészét képezi, és (3) amelynek közlésére egységesen értelmezett szimbólumrendszer alakult ki". ${ }^{24} \mathrm{~A}$ társadalmi értéket eszközjellegünek tekinti, azok „az egyének adott körében a szükségletkielégítés társadalmi eszközeinek [...] az adott körülmények között a legmegfelelőbbnek tartott állapot, képesség vagy viselkedésmód mintája". ${ }^{25}$ Rokeach szintén differenciálja az értékeket, szerepük szerint beszél cél- és eszközértékekről. Az előbbiek életvezetésünk célját (az elérni kívánt állapotot, helyzetet) adják, míg az utóbbiak a célok elérésének eszközeit szolgálják. Adott érték funkcionálhat cél- vagy eszközértékként is, a személytől függően (a gazdagság mint olyan, lehet életcél, míg másnak ez pusztán eszköz, egy tartalmas, élménydús élet megvalósításához). A cél- és eszközértékek rendszere oly mértékben meghatároznak bennünket, hogy Rokeach szerint egy személy valóját, énazonosságát, identitását legjobban a centrális értékekkel való azonosulása fejezheti ki. Ugyanez vonatkozik a társadalmi csoportokra, sőt népekre, nemzetekre is. ${ }^{26}$ Bár társadalmon belül a különböző szociológiai változók (nem, kor, társadalmi státusz stb.) eltéréseket eredményez(het)nek az egyének, csoportok értékrendszerében, az azon belüli értékprioritásokban, azonban az „értékjelenség, a preferenciális magatartás legerősebb prediktora [...] az adott nemzeti kultúra egészében keresendő". ${ }^{27}$

Az értékek személyes természetűek, belső indíttatásként jelentkeznek, ezért érzelmileg hangsúlyosak, a személyiség legmélyebben beágyazott támpontjai. Értékitéleteink alapján hozzuk döntéseinket és cselekszünk. „Az értékek szervezik, tagolják múltunkat, jelenünket és jövőnket. Orientálnak, szabályozzák testi- lelki energiáink felhasználását, behatárolják és kifejezik társadalmi hovatartozásunkat, társadalmi énünket." ${ }^{128}$ Rendszert alkotva irányítják az egyének életét, vezérlik gondolkodásukat, energetizáló erejük van a cselekvésekben, és navigálnak a helyzetek, eszközök és célok megítélése során.

Minden nemzet értékrendszere a közös tudat kikristályosodásaként tekinthető. E közös tudat tartalma és rugalmassága az emberi társulások változásával módosulhat. A korábbi társadalmakban a közös tudat nagyobb mértékben határozta meg az egyén kulturális mozgásterét, jelentős nyomaték esett a viselkedés egyöntetüségére, a kulturális formákhoz való szigorú, engedelmes ragaszkodásra. ${ }^{29}$ Tönnies

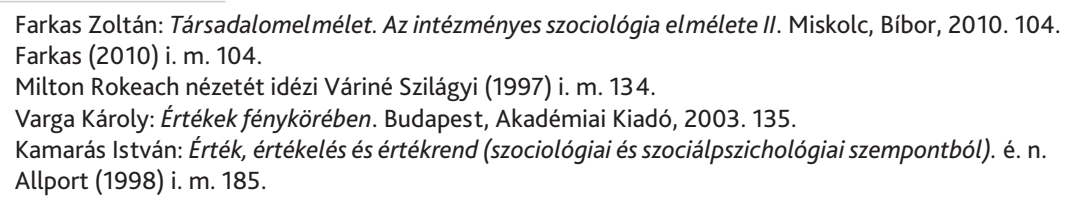


okfejtése szerint ${ }^{30}$ a hagyományokra orientált, tradicionális társadalmakban a közös értékekhez, a közös sorshoz és hagyományokhoz füződő érzelmi közösség kapcsolja elsősorban egybe az emberi társulást. Az érzelmi alapú összetartó erőt mutatja, hogy itt közös az öröm, közös a bánat, egyéni érdekek nem feszítik a közösséget. A modern társadalmakban viszont a kultúra rugalmassága jellemző, ami nagyobb mozgásteret enged az egyénnek. A társadalom kohéziójának alapja a közös célok elérésére irányuló társulás szükségességének racionális belátása, amelyet csak másodlagosan támogatnak meg az érzelmek. ${ }^{31}$ Csepeli e változásra utalva állapítja meg, hogy „a tradicionális társadalmak kollektív értékrendjét a modernizáció érvényteleníti, és helyére az egyén számára választható értékek széles kínálati spektrumát állítja". ${ }^{32}$

Az értékrendek különbözőségeitől függetlenül, a mindenkori társadalom az értékei segítségével - annak konformizáló szerepe által - szabályozni tudja önmagát. E szabályozó hatás markánsan kitapintható a 19. századi protestáns munkaerkölcs és a vele kapcsolatos érzelem- és gondolatvilág megnyilvánulásai sorában: a kemény munka, a puritán életmódra, a takarékosságra, a gazdaságosságra törekvés, és az olyan értékek hangsúlyozása, mint a mértékletességre törekvő életvitel, a szükségletek kielégítésének késleltetése, a kötelességtudat és a hedonizmus megvetése. ${ }^{33}$

\section{A szimbólumok jelentéses világa}

A kultúra lényeges vonatkozása az adott közösség egységesen értelmezett szimbólumrendszere, mivel a társadalmi jelentések intézményesült mintái, akárcsak az örökölt koncepciók, szimbolikus formákban (a nyelvben, a mítoszok, az ünnepségek, a jelképek, a ceremóniák, a szokások, a rítusok és ezek tárgyi megnyilvánulásaiban) testesülnek meg. ${ }^{34}$ „Egy olyan jelentésteli szerkezetet biztosítanak az emberek számára, amely eligazításul szolgál egymás, az őket körülvevő világ és önmaguk vonatkozásában." ${ }^{35}$ Geertz a szimbólumoknak alapvető funkcionális szerepet tulajdonít, szerinte a kultúra „a szimbólumokban megtestesülő jelentések történetileg közvetített mintáit jelöli, [...] amelynek segítségével az emberek kommunikálnak egymással, állandósítják és fejlesztik az élettel kapcsolatos tudásukat és attitüdjeiket". ${ }^{36}$ Parsons, a kultúra konstruáló elemének tekinti a szimbólumokat, „felfogása szerint a kultúra szimbólumok mintázott

30 Ferdinand Tönnies: Közösség és társadalom. Budapest, Gondolat, 1983. 6-27., 32-35., 57-59., 73-74. Tönnies könyvében az emberi társulásokban a kapcsolatok minőségét és az ezeket összetartó erőket, motivációkat próbálta elméletileg megragadni. Úgy vélte, hogy a hagyományokra orientált társadalmakban a spontán és természetes életközösségeket jelentő emberi társulás a Gemeinschaft, a közösség a domináns társulási forma, míg a modern polgári fejlődés során létrejött uralkodó társulási forma a Gesellschaft, a társadalom, amely a tagok érdekeinek és választott céljainak tudatos szolgálatába állított, e célokra orientált egyesülése.

31 Tönnies (1983) i. m. 5-33.

32 Csepeli György: Szociálpszichológia. Budapest, Osiris, 2001. 145.

33 Max Weber: A protestáns etika és a kapitalizmus szelleme. Budapest, L'Harmattan, 2018. 18-41.

34 Maróti a szimbólum szó eredetét illetően Gadamer leírását tartja hitelesnek: a régi görög társadalomban szokásos volt, hogy „a vendéglátó [...] kettétört egy cserepet, az egyik felét megtartotta, a másikat pedig a vendégnek adta, hogy ha harminc vagy ötven év múlva ő vagy a leszármazottja a házba érkezik, akkor a két töredék összeillesztésével felismerjék egymást. Valami, amiröl valakit régi barátként ismerünk fel". Maróti Andor: Amit a kultúráról tudnunk érdemes. 2019.

35 Kapitány Ágnes - Kapitány Gábor: A szimbólumok és a szimbolizáció kérdései a kulturális antropológiában III. é. n. 19.

36 Geertz (2001) i. m. 74. 
rendszereiből épül fel, amelyek a cselekvések irányultságainak a tárgyait, az egyéni cselekvők személyiségének az elsajátított összetevőit, és a társadalmi rendszerek intézményesült mintáit képezik". ${ }^{37}$

Valamennyi emberi társadalomban kimutatható a szimbólumok „énvédelmének” rendszere, a szimbólumképzés már a primitív társadalmakban megjelent. Hankiss szerint „szüntelen és lázasan igyekeztek szimbólumok védőszférájával, védőpajzsával körülvenni magukat”, „mert ez volt az egyetlen lehetőség arra, hogy életben maradjanak ezen a planétán; nem egyszerüen csak fizikailag, hanem lelkileg és szellemileg is". ${ }^{38} \mathrm{~A}$ címer mint szimbólum megjelenése is a primitív közösségektől eredeztethető. A totemnek mint emblémának a heraldikus címerrel való rokonságát erősíti meg Durkheim a primitív népek életének vizsgálata során. Az ausztrál törzseknél a totem egy-egy csoport (klán) megkülönböztető jelvénye, emblémája, úgyszintén az észak-amerikai indiánoknál a totem a civilizált országok címereinek felel meg. Az indiánok az európaiakkal való szerződéskötéskor a klán totemével (ami valójában egy rajz, egy faragás) pecsételték le a szerződést. Az észak-amerikai indiánok pajzsukra festették a totemet csatába indulás előtt, az ausztrál klánok harcosainak a sisakjukon volt a totemük. A megkülönböztető (egyben azonosító) szimbólum alkalmazása végigkövethető a történelem folyamán. A feudalizmusban a nemesek címereiket megjelenítették kastélyukon, fegyvereiken és minden más birtokolt tárgyaikon. ${ }^{39}$

A szimbólumok társadalmi létéről elmondható, hogy „minden emberi viselkedés szimbólumok használatából áll vagy attól függ. Az emberi viselkedés szimbolikus viselkedés; a szimbolikus viselkedés emberi viselkedés." ${ }^{40}$ Az alapvető szimbólumok azokat az értékeket testesítik meg, amelyek központi jelentőségűek a társadalom számára, és amelyekre a társadalom integrációja támaszkodik. Parsons szerint az értékek intézményesült mintái a kollektív reprezentációk. ${ }^{41}$ Miután ezeknek közös jelentésük van, ezért képesek az emberek, használatuk révén egymással kommunikálni. A szimbólumok a tapasztalatok sorából születnek, viszont attól elvonatkoztatva, közvetett jelentéssel rendelkeznek. Turner szerint „a rituális kontextusban használt szinte minden tárgynak, minden gesztusnak, minden dalnak vagy imának, minden térbeli vagy időbeli egységnek [...] önmagán túlmutató jelentése van. Több, mint aminek látszik, esetenként sokkal több." ${ }^{42}$ Köztudott, mit jelent a zászló a katona számára, holott önmagában csak egy vászondarab. Durkheim megfogalmazásában: „A katona, aki a zászlót védelmezve esik el, nem gondolja úgy, hogy egy vászondarabért áldozta életét." A szimbólumnak tulajdonított erényt a rész is megjeleníti, és ugyanúgy felidézi a hozzá füződő érzéseket, ezért a „zászló egyetlen kis darabkája is éppúgy jelképezi a hazát, mint az egész zászló". ${ }^{43}$

37 Talcott Parsons: The Social System. New York: Free Press, 1951. Idézi Farkas Zoltán: A kultúra a szabályok és az intézmények. Miskolci Egyetem, 2005. 8.

38 Hankiss Elemér: Az emberi kaland. Egy civilizáció-elmélet vázlata. Budapest, Helikon, 1999. 264.

39 Emile Durkheim: A vallási élet elemi formái. Budapest, L'Harmattan, 2004. 111-112.

40 Kapitány Ágnes - Kapitány Gábor: A szimbólumok és a szimbolizáció kérdései a kulturális antropológiában I. Budapest, MTA TK SZI - MOME, é. n. 1.

41 Talcott Parsons: A modern társadalmak rendszere. In Felkai Gábor - Némedi Dénes - Somlap Péter (szerk.): Szociológiai irányzatok a XX. században. Budapest, Új Mandátum, 2000. 43.

42 Victor Turner: A rituális folyamat. Budapest, Osiris, 2002. 38. Idézi Maróti Andor (2019). i. m. 6.

43 Durkheim (2004) i. m. 214-215. 
A szimbólumok körülölelik életünket, bennük az emberi közösség különböző szféráinak (életterületeinek) jelentést hordozó mozzanatai tükröződnek. E jelenségek hálózatszerű rendszereiben mintegy összesürűsödnek a mindenkori társadalom üzenetei, értelmezései. A társadalmi folyamatok függvényében a szimbólumok képesek újabb s újabb jelentéstartalmakat magukhoz társítani. ${ }^{44} \mathrm{~A}$ nemzeti színú zászlóhoz újabb tartalmat kapcsol a lyukas nemzeti zászló. A sírjelként szolgáló (hagyományos csónak alakú) fejfa helyett a kopjafa (mint ősi, keleti harci eszköz) magyarságszimbólum is. ${ }^{45}$ Szimbolikák jelenítik meg a társadalom közös tudattartalmát, mindamellett őrzik a múltat, és egyesítve őket továbbadják a jövőnek. Így biztosítva a múlt, jelen és jövő egymásba kapcsolódását. A múlt örökségét valamennyi emberi társulás szimbolikus formákban kifejezett tartalmakkal ápolja. Ezért a szimbólumrendszerek jelentései nem érthetők meg attól a kultúrától elszigetelten, amelybe beágyazódtak. ${ }^{46}$ Ugyanazt a dolgot és jelenséget a különböző nyelvek másképpen fejezik ki, a név jelentése csak az adott kultúrában lesz általánosan elfogadott, egy expresszív szimbolika üzenete egy másik kultúrában teljesen más értelmú lehet.

A szimbólumelemek mindig valamilyen érzelmi viszonyulást váltanak ki az egyénből (ami lehet erősebb vagy gyengébb) és viselkedése motivációjaként léphetnek fel. A nemzeti zászló, a himnusz, a kereszt vagy a nemzeti viselet a meglévő identitás erős érzését hozza felszínre. Az érzelemkeltő funkción túl, társadalomszervező funkciója is van, miután a szimbólumokban megtestesülő értékjelentések hálói befolyásolják a cselekvéseket. ${ }^{47} \mathrm{~A}$ közösen vallott szimbólumok az együvé tartozás kifejezői, közösségteremtő funkcióval. Farkas szerint „az egységesen értelmezett szimbólumrendszer [...] fényében értelmezett tapasztalat eredményeként válhat az adott tudattartalom általánossá az egyének adott körében, [ ] s ismerik fel az egyes egyének, hogy mások is osztoznak az adott tudattartalomban" ${ }^{48}$ Minden társadalom törekszik arra, hogy rendszeresen megerősítse a sajátos arculatát biztosító kollektív érzéseket és gondolatokat. Ezért a szimbólumokban szervesült jelentések időnkénti újabb és újabb (nyelvi, képi, viselkedésbeli) kollektív megjelenítése a hozzájuk kapcsolódó érzelmek tartósságát hivatottak őrizni, míg a hősök, példaképek felidézésével (a cselekedetükben megtestesült értékek által) az elismerésre, tiszteletre méltó, a kívánatos magatartás nyer megerősítést.

Durkheim szerint a szimbólumképzés a hatásgyakorlás eszközeként is megjelenhet, azt a képzetet kínálva, hogy befolyásolni tudjuk az eseményeket. Így a mag ültetésekor elmondott ima a jó termés reményét adja, vagy halászatkor a jó fogással történő hazatérést segíti elö. Úgyszintén az élet nagy fordulópontjait is minden társadalomban ünneppel, szertartásokkal kapcsolják össze, átsegítve ezzel az embert a születés, a serdülés és a meghalás tragédiáján. A temetési rituálé megkönnyíti a gyászoló(k) nak az új élethelyzettel való szembenézést. A rítusoknak valódi funkciója a közösség

44 Kapitány Ágnes - Kapitány Gábor: A szimbólumok és a szimbolizáció kérdései a kulturális antropológiában II. Budapest, MTA TK SZI - MOME, é. n. 4.

45 L. Juhász részletesen taglalja („Kopjafa” versus hagyományos fejfa?) a fejfák, illetve a „folklorizmus-kopjafák” állításának gyakorlatát és annak szabályozását a hajdúböszörményi hagyományos csónak alakú fejfás védett temetőrész bemutatása során. L. Juhász Ilona: Rítusok, jelek, szimbólumok. Somorja-Komárom, Fórum Kisebbségkutató Intézet Etnológiai Központ, 2011. 190-197.

46 Anthony Giddens: Szociológia. Budapest, Osiris, 1997. 68.

47 Geertz (2001) i. m. 74-78.

48 Farkas (2005) i. m. 8. 
szolidaritásának és kohéziójának a fenntartása és megerősítése. ${ }^{49}$ Érzelmeink kifejezését is szimbólumok segítségével tesszük, de ugyanígy, egyes interakciós helyzetekben mások viselkedési mintáinak megértése is csak a szimbólumok ismeretében lehetséges. A kollektív szimbólumok mellett vannak egyéni szimbólumok is. „Lehet személyes kifejező szimbólum vagy szimbolikus rendszer például a szeretet, a helyeslés és megbecsülés kinyilvánításának valamilyen formája, az öltözet, a mủalkotás, az üdvözlés, a születésnap, a vallási szertartás."150

\section{5. Összegezve}

A társadalom szövevényes mintázatú jelképes kultúrája egységes keretbe integrálja a közösséget és tagjai számára az identitás megélését biztosítja. A szocializáció során elsajátított „közös tudat” a társadalmi szolidaritás megalapozója, az e mögötti ismeretanyag segíti az embereket egymás megértésében. A társadalmi rend kiszámíthatóságát, az együttélés feltételét a normarendszer teremti meg. Az elvek, szabályok megerősítését szankciókkal alátámasztott normakontroll szolgálja. A kultúra építőkövei a kultúrspecifikus eszmei objektivációként létező értékek, és ezek konformizáló szerepe által szabályozza önmagát a társadalom. A rendszerbe szerveződött értékek a személyiség legmélyebben beágyazott támpontjai, motiváló, energetizáló erővel hatnak. A társadalom közös tudattartalmát a jelentéssel rendelkező szimbólumok jelenítik meg, amelyek egyben őrzik a múltat, körbefonják a jelent, és továbbadják a jövőnek, valóra váltva a kultúra átörökítését.

\section{Felhasznált irodalom}

Allport, Gordon W.: A személyiség alakulása. Győr, Kairosz, 1997.

Andorka Rudolf: Bevezetés a szociológiába. Budapest, Osiris, 1997.

Csepeli György: Szociálpszichológia. Budapest, Osiris, 2001.

Csink Lóránt - Mayer Annamária: Variációk a szabályozásra. Budapest, Médiatudományi Intézet, 2012. Online: https://mek.oszk.hu/13500/13526/13526.pdf

Durkheim, Emile: A társadalmi munkamegosztásról. Budapest, MTA Szociológiai Kutató Intézet, 1986.

Durkheim, Émile: A vallási élet elemi formái. Budapest, L'Harmattan, 2004.

Elias, Norbert: A civilizáció folyamata I-II. Budapest, Gondolat, 1987.

Falkné Bánó Klára: Kultúraközi kommunikáció. Az interkulturális menedzsment aspektusai. Budapest, Perfekt, 2008.

Farkas Zoltán: A kultúra a szabályok és az intézmények. Miskolci Egyetem, 2005. Online: http://midra.uni-miskolc.hu/document/11758/3695.pdf

Farkas Zoltán: Társadalomelmélet. Az intézményes szociológia elmélete II. Miskolc, Bíbor, 2010. Online: https://mek.oszk.hu/14800/14863/pdf/14863_2.pdf

49 Durkheim (2004) i. m. 151-159., 210-215., 361-366.

50 Talcott Parsons: The Social System. New York, The Free Press, 1951. 389. Idézi Farkas (2005) i. m. 11. 
Foucault, Michel: Felügyelet és büntetés. Budapest, Gondolat, 1990.

Geertz, Clifford: Az értelmezés hatalma. Antropológiai írások. 2. kiadás. (Válogatás, utószó Niedermüller Péter). Budapest, Osiris. 2001.

Giddens, Anthony: Szociológia. Budapest, Osiris, 1997.

Goffman, Erving: A hétköznapi élet szociálpszichológiája. Budapest, Gondolat, 1981.

Hankiss Elemér: Az emberi kaland, Egy civilizáció-elmélet vázlata. Budapest, Helikon, 1999.

Hankiss Elemér: Proletár reneszánsz. Tanulmányok az európai civilizációról és a magyar társadalomról. Budapest, Helikon, 1999.

Heller Ágnes: A szándéktól a következményig. Budapest, Magvető, 1970.

Heller Ágnes: Általános etika. Budapest, Cserépfalvi, 1994.

Hofstede, Geert: Culture's Consequences. International Differences in Work-Related Values. London - Beverly Hills, Sage, 1980.

Kamarás István: Érték, értékelés és értékrend (szociológiai és szociálpszichológiai szempontból). é. n. Online: www.metaelmelet.hu//pdfek/tanulmanyok/ertek_ertekeles.pdf

Kapitány Ágnes - Kapitány Gábor: A szimbólumok és a szimbolizáció kérdései a kulturális antropológiában I. Budapest, MTA TK SZI - MOME, é. n. Online: http:// webcache.googleusercontent.com/search?q=cache:YqD-yyl8hloJ:www.tit.hu/ studio/Szimbolumok_1.pdf+\&cd=2\&hl=hu\&ct=clnk\&gl=hu

Kapitány Ágnes - Kapitány Gábor: A szimbólumokés a szimbolizáció kérdései a kulturális antropológiában II. (Bachofentöl Sperberig). Budapest, MTA TK SZI - MOME, é. n. Online: http://webcache.googleusercontent.com/search?q=cache:Ot2_12NJpzMJ:www.tit.hu/studio/Szimbolumok_2.pdf+\&cd=3\&hl=hu\&ct=clnk\&gl=hu

Kapitány Ágnes - Kapitány Gábor: A szimbólumok és a szimbolizáció kérdései a kulturális antropológiában III. Budapest, MTA TK SZI - MOME, é. n. Online: http://webcache.googleusercontent.com/search?q=cache:3m2gY0qtkZsJ:www.antroport. hu/wp-content/uploads/2016/03/Kapitany-Szimbolizacio-III..pdf+\&cd=1\&hl=hu\&ct=clnk\&gl=hu

Kolb, William L.: Azértékfogalom jelentőségének változása a mai szociológiai elméletben. In Balog László (szerk.): Modern polgári szociológia IV. Budapest, Tankönyvkiadó, 1966. 241-253.

L. Juhász Ilona: Rítusok, jelek, szimbólumok. Somorja-Komárom, Fórum Kisebbségkutató Intézet Etnológiai Központ, 2011. Online: https://mek.oszk.hu/10300/10315/10315.pdf

Maróti Andor: Amit a kultúráról tudnunk érdemes. 2019. Online: https://mek.oszk. hu/19300/19385/19385.htm

Pangákisz Grigóriosz L.: Civilizáció és kultúra. Kultúra és Közösség, 7. (2003), 1. 71-86. Talcott Parsons: The Social System. New York, The Free Press, 1951.

Parsons, Talcott: A modern társadalmak rendszere. In Felkai Gábor - Némedi Dénes - Somlai Péter (szerk.): Szociológiai irányzatok a XX. században. Budapest, Új Mandátum, 2000.

Rudnák Ildikó: A multikulturális környezet kihívásai a magyarországi nagyvállalatok vezetöi körében. Doktori értekezés. Gödöllö, Szent István Egyetem, 2010. Online: https://kisebbsegkutato.tk.hu/uploads/files/olvasoszoba/multikulturalizmus/ Rudnak_Ildiko_ertekezes.pdf 
Szigeti Péter: Norma és valóság. Győr, Széchenyi István Egyetem, MTA Politikai Tudományok Intézete, 2006. Online: https://mek.oszk.hu/04000/04073/04073.pdf Tönnies, Ferdinand: Közösség és társadalom. Budapest, Gondolat, 1983.

Victor Turner: A rituális folyamat. Budapest, Osiris, 2002.

Varga Károly: Értékek fénykörében. Budapest, Akadémiai Kiadó, 2003.

Váriné Szilágyi Ibolya: Az ember, a világ és az értékek világa. In Lengyel Zsuzsanna (szerk.): Szociálpszichológia. Budapest, Osiris, 1997. V. fejezet. Online: https://regi. tankonyvtar.hu/hu/tartalom/tkt/szocialpszichologia/ch05s04.html\#id504400

Vitányi Iván: A kultúra szerepe a társadalomban és a demokráciában. Beszélő, (2016), március 6. Online: http://beszelo.c3.hu/onlinecikk/a-kultura-szerepe-a-tarsadalomban-es-a-demokraciaban

Weber, Max: A protestáns etika és a kapitalizmus szelleme. Budapest, L'Harmattan, 2018. 